\begin{tabular}{|c|c|c|}
\hline \hline & $\begin{array}{c}\text { International Journal of Current Research in } \\
\text { Biosciences and Plant Biology }\end{array}$ \\
\hline EXCELLENT \\
PUBLISHERS
\end{tabular}

\title{
Cultivation of Rabies Virus Strain of the "Kazsrvi" in Cell Culture
}

\author{
B.Sh. Myrzakhmetova and L.B. Kutumbetov*
}

Kazakh Scientific Research Veterinary Institute, Almaty, Republic of Kazakhstan

*Corresponding author.

\section{Abstract}

The article presents the results of cultivation of the laboratory strain of rabies virus in the cell cultures of BHK-21 and TN-KK49 in successive passages, which was carried out in different ways. In one case the passages was performed by transferring of infected cell cultures, in the other case - by introducing to the new batch of intact cells the suspension of infected cell cultures of the previous passage. It was established that both kinds of used cell culture are susceptible to rabies virus and it can be passaged in these substrates tested with these both ways. The cultural virus of the third passage preserves its pathogenicity with respect to mice at intracerebral infection.

\section{Article Info}

Accepted: 31 August 2017

Available Online: 06 September 2017

\section{Keywords \\ Infection \\ Passage \\ Rabies virus \\ Substrates \\ Suspension}

\section{Introduction}

Rabies virus was cultured in the organism of various species of animals (laboratory and farm) and outside the organism - in the cell cultures (Baldina, 2004; Buchnev, 1986) for virological research and for manufacture of diagnostic's and vaccine's product. A method of using donor animals for production of viral mass is technologically insufficient. Therefore, the basis of technologies for manufacture of modern antirabies vaccine is a method of viral mass production in cell culture (Cherkasski, 1985; Syurin et al., 1998). At the same time the technological methods of production of viral feedstock of the rabies virus pathogen, depending on the biological properties of used strain, the type and method of cell culture cultivation is differ significantly. However up to the present moment production of rabies virus in cell culture is not carried out in our country.
There are only researches and production of a fixed strain of this virus in the brain tissue of laboratory and farm animals.

The aim of studies is to determine the reproductive capacity of the laboratory's strain of fixed rabies virus in passaged cell cultures with haploid and diploid set of chromosomes.

\section{Materials and methods}

The studies used laboratory's strain of fixed rabies virus, which can be reproduced in vitro and in vivo, in the cell culture of BHK-21 and TN-KK49. Cells were grown by monolayer stationary method in the Eagle's nutrient medium with adding of $10 \%$ serum of cattle blood. For the purpose of virus production the given virus titer with $10^{5.0} \mathrm{MLD}_{50} / \mathrm{cm}^{3}$ was added to the cell monolayer in 3- 
4 days age in a dose of $5 \mathrm{~cm}^{3}$ of a 1.5 liter mattress containing $100 \mathrm{~cm}^{3}$ Eagle medium without serum. The cells in the flasks were inoculated with the virus, incubated at $37^{\circ} \mathrm{C}$ within one hour, then medium was replaced with refreshed, adding serum containing 5\% blood cattle embryos. Following the BHK-21 cells were incubated for further treatments at the same temperature for 5 days, and TN-KK49 - within 7 days. Upon completion of the cultivation period there were performed the "blind" passaging of the virus in both cell culture. In one case, some of the cells in the culture flasks were passaged by reseeding, in the other case - by transfer of the virus-containing suspension culture, which were subjected to a physical destruction of the cells, in a fresh monolayer of cells. In every way, it was held up to 4-5 passages and on the $3^{\text {rd }}$ and $5^{\text {th }}$ passages the viral titer were studied. The virus titer was adjusted with a bioassay on suckling mice by the intracerebral infection with the tenfold dilutions of the test samples. The presence of virus in the test culture suspension was determined by the disease and the death of mice subjected to bioassay.

The reproductive capability of the virus "in vitro" in the used biological model was evaluated by its titer in each cell culture. The comparative cell culture performance was calculated by the number of the virus in a total volume of biomass from the minimum time.

\section{Results and discussion}

Each viral passage was carried out in parallel in two kinds of cell cultures, BHK-21 and TN-KK49 grown in 1.5 liter flasks. The virus was used for infection and subsequent passaging on 4 cell culture flasks with fresh formed monolayer, the formation of which on the third day adjusted inoculum concentrations of the trypsinized cells. For this, theBHK-21 culture cells were seeded at a concentration of $2 \times 10^{5}$ cells $/ \mathrm{cm}^{3}$, and TN-KK49 culture cells - at the concentration of $4 \times 10^{5} / \mathrm{cm}^{3}$. For the comparative evaluation of the dynamics of cell proliferation, subjected to infection with intact virus, the control cell culture was used for each species grown in 3 flasks and not subjected to a virus infection. At each virus passage, before and after cultivation, the concentration of living cells was determined. In cell culture, wherein the virus passaging was performed by subculturing with trypsin solution, the timing and nature of the monolayer formation were evaluated. The results for cell cultivation passages of non-infected and infected with rabies virus listed in Table 1.
As can be seen from Table 1, in the control culture BHK-21 cells at a seeding concentration of $2 \times 10^{5}$ cells $/ \mathrm{cm}^{3}$ with the total amount of $2.4 \times 10^{7}$ on the first passage the monolayer was formed on the third day and after 5 days of further culturing cells they increased to 5 reaching the total $1.2 \times 10^{8}$. Approximately the same rate of growth and accumulation concentration the culture has in the following 2 passages. In the passaging intact cell culture TN-KK49 its proliferative activity was relatively lower than the cell culture of BHK-21, and its index was within 2.9. Taking into account such a slowspeed growth of the culture cells in order to obtain a uniform monolayer of cells in the same time frame and BHK-21 cells ( $3 \mathrm{~d}$ day) was used twofold increased inoculum concentration of cells, with a total of $4,8 \mathrm{~h} 107$ cells. In such a quantity the cell culture formed a monolayer in the expected period, and after following 5 days of culture the total number of cells in each mattress was $1.4 \times 10^{8}$. Two additional passages which were performed with the same parameters of sowing and cell cultivation, as well as the first passage, growth rate and accumulative number of cells were approximately equal. The changing of the speed of the monolayer formation and its character were marked in the cell culture population passaged after infected with rabies virus. In a monolayer of such cells culture the CPE virus was not detected. However, from passage to passage there was a prolongation of forming the monolayer and changing its character toward "disintegration". Thus, when the total number of plated cells BHK-21 equal to $4 \times 10^{7}$ and TNKK49 $-4.8 \times 10^{7}$ and infected with the virus on the third day, after further 5 days of cultivation, the amount of cells was grown to $1,1 \mathrm{~h} 108$ for BHK-21 and $1.2 \times 10^{8}$ for TN-KK49 cells.

The proliferation index was equal to 4.58 and 2.5, respectively. That is, in both cell cultures, the growth rate slowed down to 0.42-0.4. In the following two passages carried out by trypsinization, with the total number of sown cells, which was equal to the quantity that used during the first passage, to the 9th day of culture on the second passage and $10-11^{\text {th }}$ passage on the third day, the total number of grown cells was $1.0 \times 10^{8}$ for the line BHK-21 and $0.9 \times 10^{8}$ for TN-KK49 in the second passage and $0.8 \times 10^{8}, 0.7 \times 10^{8}$, respectively, in the third passage. The calculation of digital indicators and the number of sown cells grown on each type showed that the proliferation index of BHK-21 cells was 4.17 in the second passage, and 3.3 in the third passage. While these figures in culture TYA-KK49 cells were equal to 1.88 in the second passage and 1.46 in the third passage. 
Table 1. The concentration of seed and growth of cell cultures with and without rabies virus at the different methods of passage

\begin{tabular}{|c|c|c|c|c|c|c|c|c|c|c|c|}
\hline \multirow[b]{3}{*}{$\begin{array}{l}\text { Methods of } \\
\text { passage }\end{array}$} & \multirow[b]{3}{*}{$\begin{array}{l}\text { The cell } \\
\text { culture }\end{array}$} & \multirow[b]{3}{*}{$\begin{array}{l}\text { The cell } \\
\text { culture } \\
\text { status }\end{array}$} & \multicolumn{9}{|l|}{ Passages number } \\
\hline & & & \multicolumn{3}{|l|}{ First } & \multicolumn{3}{|l|}{ Second } & \multicolumn{3}{|l|}{ Third } \\
\hline & & & $\begin{array}{l}\text { The sowing cell } \\
\text { concentration }\end{array}$ & $\begin{array}{l}\text { The } \\
\text { cultivation } \\
\text { period, } \\
\text { days }\end{array}$ & $\begin{array}{l}\text { The total } \\
\text { amount } \\
\text { of grown } \\
\text { cells }\end{array}$ & $\begin{array}{l}\text { The sowing cell } \\
\text { concentration }\end{array}$ & $\begin{array}{l}\text { The } \\
\text { cultivation } \\
\text { period, } \\
\text { days }\end{array}$ & $\begin{array}{l}\text { The total } \\
\text { amount } \\
\text { of grown } \\
\text { cells }\end{array}$ & $\begin{array}{l}\text { The sowing } \\
\text { cell } \\
\text { concentration }\end{array}$ & $\begin{array}{l}\text { The } \\
\text { cultivation } \\
\text { period, } \\
\text { days }\end{array}$ & $\begin{array}{l}\text { The total } \\
\text { amount } \\
\text { of grown } \\
\text { cells }\end{array}$ \\
\hline Subcultures & ВНК-21 & $\begin{array}{l}\text { Without } \\
\text { virus }\end{array}$ & $2.4 \times 10^{7}$ & 8 & $1.2 \times 10^{8}$ & $2.4 \times 10^{7}$ & 8 & $1.3 \times 10^{8}$ & $2.4 \times 10^{7}$ & 8 & $1.4 \times 10^{8}$ \\
\hline \multirow{3}{*}{ Subcultures } & TN-KK49 & $\begin{array}{l}\text { Without } \\
\text { virus }\end{array}$ & $4.8 \times 10^{7}$ & 8 & $1.4 \times 10^{8}$ & $4.8 \times 10^{7}$ & 8 & $1.3 \times 10^{8}$ & $4.8 \times 10^{7}$ & 8 & $1.3 \times 10^{8}$ \\
\hline & ВНК-21 & $\begin{array}{l}\text { With } \\
\text { virus }\end{array}$ & $2.4 \times 10^{7}$ & 8 & $1.1 \times 10^{8}$ & $2.4 \times 10^{7}$ & 9 & $1.0 \times 10^{8}$ & $2.4 \times 10^{7}$ & 10 & $0.8 \times 10^{8}$ \\
\hline & TN-KK49 & $\begin{array}{l}\text { With } \\
\text { virus }\end{array}$ & $4.8 \times 10^{7}$ & 8 & $1.2 \times 10^{8}$ & $4.8 \times 10^{7}$ & 9 & $0.9 \times 10^{8}$ & $4.8 \times 10^{7}$ & 11 & $0.7 \times 10^{8}$ \\
\hline $\begin{array}{l}\text { Transferring } \\
\text { (contamination) }\end{array}$ & ВНК-21 & $\begin{array}{l}\text { With } \\
\text { virus }\end{array}$ & $2.4 \times 10^{7}$ & 8 & $1.1 \times 10^{8}$ & $2.4 \times 10^{7}$ & 8 & $1.3 \times 10^{8}$ & $2.4 \times 10^{7}$ & 8 & $1.2 \times 10^{8}$ \\
\hline monolayer & TN-KK49 & $\begin{array}{l}\text { With } \\
\text { virus }\end{array}$ & $4.8 \times 10^{7}$ & 8 & $1.2 \times 10^{8}$ & $4.8 \times 10^{7}$ & 8 & $1.2 \times 10^{8}$ & $4.8 \times 10^{7}$ & 8 & $1.1 \times 10^{8}$ \\
\hline
\end{tabular}


Thus, infection of cell cultures of BHK-21 and TNKK49 with rabies virus does not cause a visible CPE in monolayer, but slows down the process of an active cell growth. The proliferation index of cells with each additional passage conducted by trypsinization passages was decreased in direct proportion to the number of passages.

In studies conducted in parallel passages where the virus was carried out by transferring the suspension of the infected cells in the monolayer fresh intact cells, the changes of cell proliferation index in all three successive passages are not mentioned. Quantitatively, it was equal to 4.58 in the first passage, 5.41 in the second passage and 5.0 in the third for the BHK-21 cells, for the cell culture TN-KK49, the figure was 2.5 in the first and second passages and 2.29 on the third passage.

In order to establish the specificity of the proliferation activity retardation of the population of cell cultures infected with rabies virus and confirmation of the presence of the virus in cell culture samples in which the passages of the virus was conducted by transfer suspension of infected cells to a new monolayer the studies on the detection of the pathogen in these cell cultures were conducted by bioassay on suckling mice. The data from these studies are presented in Table 2.

Table 2. Results of bioassay by the cell suspension cultures intact and infected with rabies virus after the third passage.

\begin{tabular}{|c|c|c|c|c|c|c|}
\hline \multirow{2}{*}{$\begin{array}{l}\text { The suspension } \\
\text { of infected cell } \\
\text { culture }\end{array}$} & \multirow{2}{*}{$\begin{array}{l}\text { The level of } \\
\text { the virus } \\
\text { passage }\end{array}$} & \multirow{2}{*}{$\begin{array}{l}\text { Method of } \\
\text { passaging }\end{array}$} & \multirow{2}{*}{$\begin{array}{l}\text { The number of } \\
\text { infected mice, } \\
\text { quantity }\end{array}$} & \multicolumn{3}{|c|}{ The results of bioassay } \\
\hline & & & & $\begin{array}{l}\text { Got sick, } \\
\text { quantity }\end{array}$ & $\begin{array}{l}\text { Died, } \\
\text { quantity }\end{array}$ & $\begin{array}{l}\text { Survived, } \\
\text { quantity }\end{array}$ \\
\hline \multirow[t]{2}{*}{ ВНК-21 } & 3 & Subcultures & 3 & 3 & 3 & 0 \\
\hline & 3 & $\begin{array}{l}\text { Transferring on a } \\
\text { new monolayer }\end{array}$ & 4 & 4 & 4 & 0 \\
\hline \multirow[t]{2}{*}{ TN-KK49 } & 3 & Subcultures & 4 & 4 & 4 & 0 \\
\hline & 3 & $\begin{array}{l}\text { Transferring on a } \\
\text { new monolayer }\end{array}$ & 4 & 4 & 4 & 0 \\
\hline $\begin{array}{l}\text { BHK-21 - } \\
\text { control }\end{array}$ & $\begin{array}{l}3 \text { - without } \\
\text { virus }\end{array}$ & Subcultures & 5 & 0 & 0 & 5 \\
\hline $\begin{array}{l}\text { TN-KK49 - } \\
\text { control }\end{array}$ & $\begin{array}{l}3 \text { - without } \\
\text { virus }\end{array}$ & Subcultures & 4 & 0 & 0 & 4 \\
\hline
\end{tabular}

As can be seen from Table 2, all suckling mice which were infected intracerebrally by the samples of cell culture suspension infected with rabies virus of the third passage got sick and died while similar laboratory animals infected with the samples of suspensions of cell culture and not contaminated remained healthy and alive. The results show that the rabies virus after the initial application is continuously reproduced in a population of cells BHK-21 and TN-KK49 for all three passages regardless of the method of its passage.

\section{Conclusion}

The results of the research give reason to conclude that the laboratory strain of the fixed rabies virus manages to produce in the cell cultureline BHK-21 and passaged diploid culture TYA-KK49 cells by direct passages with trypsinization and making a suspension of infected cell culture after freezing and thawing the new party cell culture. When passaging the virus in cell cultures of BHK-21 and TN-KK49 by passages beginning from the second passage there is a decrease in proliferative activity of these biological models, and in the passages with a new batch of cell cultures - their rate of reproduction remain on the level of the control cell culture.

\section{Conflict of interest statement}

Authors declare that they have no conflict of interest.

\section{References}

Baldina I.V., 2004. Epizootological Basics of Rabies Virus Prophylaxy Improvement in Moscow Region, 
Dissertation, Moscow.

Buchnev, K.N., 1986. Rabid Animals. Problems and Perspectives (The Diseases of Farm Animals), AZVI Essays, Alma-Ata.

Cherkasski, B.L., 1985. Epidemiology and Rabies
Prophylaxy, Moscow, Medicina. Syurin, V.N., Samuilenko, A.Y., Soloviev, B.V., Fomina, N.V., 1998. Virus diseases of animals; Moscow, Russian Scientific Research Technological Institute of Biological Industry.

\section{How to cite this article:}

Myrzakhmetova, B.Sh., Kutumbetov, L.B., 2017. Cultivation of rabies virus strain of the "Kazsrvi" in cell culture.

Int. J. Curr. Res. Biosci. Plant Biol. 4(9), 24-28. doi: https://doi.org/10.20546/ijcrbp.2017.409.005 